\title{
Influence of soil physical factors on productivity of herbaceous forage species in Kivaa and Ntugi rangelands in Eastern Kenya
}

\author{
Karugia E. ${ }^{{ }^{*}}$ Kariuki F. ${ }^{1}$, Mwaniki J. ${ }^{1}$ \\ ${ }^{1 * 1}$ Department of Plant Sciences, Kenyatta University, P. O. Box 43844-00100, Nairobi, Kenya \\ ${ }^{1 *}$ Corresponding Author. Email: karugia.elijah@ku.ac.ke
}

Received: 15 July 2020 / Accepted: 27 September 2020 / Published online: 20 November 2020

\section{ABSTRACT}

Rangelands are extensive tracts of land with natural vegetation which is the main forage resource for domestic and wild ungulates. This study investigated the influence of soil texture, bulk density, and moisture content on the production of herbaceous forage species biomass in Kivaa and Ntugi rangelands in Eastern Kenya. Stratified random sampling was used where one out of four blocks of the target rangelands was picked and three belt transects established. Along the belt transects, ten experimental plots of 5 metres by 5 metres were established at intervals of 5 metres. Key forage species were identified using a structured questionnaire administered to key informants. Soil samples were collected from the experimental plots and analyzed for soil texture, bulk density and moisture content. Forage samples were collected and dry matter weight determined. The data collected were analyzed using both descriptive and inferential statistics especially tabulation and regression respectively. The study identified the most valuable forage species namely, Dichanthium annulatum, Themeda triandra, Cenchrus ciliaris, Rhynchelytrum repens, Digitaria abyssinica, Chloris roxburghiana and Cyperus rotundus. Soils in Ntugi ranged from clay loam to sandy clay while those from Kivaa ranged from silty loam to sandy loam. There was higher moisture content in soils in Ntugi than soils in Kivaa $(t=7.71, P \leq 0.05)$. Soil moisture content had significant influence on herbage production in both Kivaa $(\mathrm{R}=0.968, \mathrm{P} \leq 0.05)$ and Ntugi $(\mathrm{R}=0.962$, $\mathrm{P} \leq 0.05)$. Soil bulk density significantly influenced forage grass species herbage production in Ntugi in 2014 ( $\mathrm{R}=$ $0.513, \mathrm{P} \leq 0.05)$ and in $2016((\mathrm{R}=0.632, \mathrm{P} \leq 0.05)$. This study concluded that soil texture, bulk density and moisture content significantly influenced herbaceous forage production in the two rangelands. The study
\end{abstract}

recommends use of rotational grazing systems combined with proper stocking rates to maintain moderate soil bulk density and good levels of soil moisture for the herbaceous forage species to continue producing adequate biomass while maintaining residual foliage for continued primary production.

Key words: Rangeland, bulk density, herbaceous forage, biomass

\section{INTRODUCTION}

In Kenya, arid and semi-arid rangelands cover about 80 per cent of the total land surface and support over 14 million people and $70 \%$ of the total country's livestock population (MacOpiyo et al., 2013). Kenyan rangelands are characterized by low and erratic precipitation and recurrent, prolonged and severe droughts. These conditions lead to seasonal variation in both quality and quantity of forage which adversely compromise livestock production in most of the counties with extensive arid and semiarid rangelands (Gikaba et al., 2014). Soil characteristics influence quality and quantity of forage produced in rangelands as it is the source of nutrients, moisture and oxygen which are key ingredients for proper plant growth and productivity (Freysen \& Woldendorp, 1978). The physical properties of the soil have indirect effects on soil $\mathrm{pH}$, which influences nutrient uptake by plants, and this will directly influence plant survival, growth and performance (Caplan \& Yeakley, 2006).

Plant growth is affected by the amount of moisture and air in the soil. Soil moisture retention capacity and amount of air held in the soil pore spaces are functions of soil 
texture. Coarse textured soils, like sand usually have large air spaces and can hold large volumes of air during rainfall storms but have low water retention due to weak cohesive and adhesive forces which allow water held to easily drain or evaporate. Soils belonging to different textural classes exhibit differences in water retention capacities, with sandy soils on average retaining about $101.6 \mathrm{~mm}$ of available water within the rooting depth $(1.22 \mathrm{~m})$, while loam and clay soils retain $152.4 \mathrm{~mm}$ and $177.8 \mathrm{~mm}$ respectively within the same depth of plant root penetration (GoA, 2020).

Soil bulk density is the mass of dry soil per unit of bulk volume, including the air space. Soil bulk density is a function of soil type or texture, and it can vary substantially among different soil types. Soil bulk density is affected by management practices such as tillage, livestock grazing and timber harvesting (Carter, 1990). Incorporation of large amounts of organic matter into the soil will lower the bulk density and increase its water retention capacity (Kranz et al., 2020). Activities and processes that compact the soil will increase bulk density. Generally, the bulk density of mineral soils ranges from 1.0 to $1.8 \mathrm{~g} / \mathrm{cm} 3$ (Arshad et al., 1996). Past research has established that, under humid conditions, soil compaction leads to decrease in crop yields (DeJong et al., 2001). Lack of sufficient data on the impact of bulk density on forage plants biomass production informed the reason for conducting this study. This study therefore sought to establish whether some level of soil compaction (though it might restrict water movement through the soil profile) could be beneficial under arid conditions. The general objective of the study was to investigate the influence of soil physical factors on production of herbage among key herbaceous forage species in Kivaa and Ntugi rangelands in Eastern Kenya. Specifically, the study sought to investigate the influence of soil moisture, texture and bulk density on forage biomass production among key herbaceous species in Kivaa and Ntugi rangelands in Eastern Kenya. The findings of this study will guide in development of viable strategies for proper management of soil and forage in Kenyan rangelands.

\section{METHODOLOGY}

\section{Study Sites}

The study was conducted in Kivaa in Masinga Sub-county of Machakos County and Ntugi in Tharaka South Subcounty in Tharaka Nithi County in Eastern Kenya (Figure 1). These two rangeland areas host forested hills which serve as rangeland watersheds. Kivaa Hill is located $0^{0}$ $52^{\prime} 0.40^{\prime \prime} \mathrm{S}$ and $37^{\circ} 43^{\prime} 4.30^{\prime \prime} \mathrm{E}$ and having elevation of 1115 metres above sea level. Kivaa rangeland falls within
Ecological zone V (arid), and it experiences frequent and recurrent droughts. Sandy soils dominate, but there are a few pockets of sandy clay soils. Ntugi Hill is located $0^{\circ}$ $11^{\prime} 55.25^{\prime \prime} \mathrm{S}$ and $37^{\circ} 55^{\prime} 33.96^{\prime \prime} \mathrm{E}$ (Figure 1). It is a forest reserve with elevation of 1099 metres above sea level. Ntugi rangeland soils range from clayey to sandy loam, with some denuded areas having rock outcrops.



Figure 1. Map of Kenya showing location of Kivaa and Ntugi rangelands in Eastern Kenya. Source: RCMRD (2016)

\section{Sampling Methods}

Stratified random sampling was used, where each of the two rangelands was divided into four blocks (Northern, Eastern, Southern and Western blocks), and one block of about 30 square metres was randomly selected from the four blocks numbered one (1) to four (4). Systematic random sampling was then used to establish experimental plots along the belt transects (replicated thrice) within the selected block. Thirty experimental plots of five (5) metres by five (5) metres were established in the three transects, and their locations identified using geographical coordinates taken using a GPS. In each plot, one sub-plot measuring $1 \mathrm{~m}$ x $5 \mathrm{~m}$ was randomly picked using a $1 \mathrm{metre}$ by 1 metre wire frame (quadrat), whereby one side of the frame was extended to cover 5 metres. It is from ten of the randomly established sub-plots that forage and soil samples for soil texture, bulk density and moisture analysis were obtained. 
Locally important herbaceous forage species were identified using a structured questionnaire, which was administered to twenty purposefully selected key informants, who included selected local agro-pastoralists, elders, and livestock production and extension officers from the County Department of Agriculture. Using the local names of the plants given by respondents, a field guide book by Maundu et al. (1999), which contains a list of useful plants of the Kenyan rangelands with their common and scientific names, was used to confirm the actual names. Some local residents were picked and trained as data collection assistants to help in the survey, and also during soil and forage samples collection.

Visits were conducted to the two rangelands during a dry season (January) and a wet season (early June) to carry out observations, conduct interviews on the purposefully selected respondents and collect soil and forage samples for analysis. The twenty respondents were interviewed using the structured questionnaire, which required them to identify the plant species that they considered to be important forage species, based on their observed preference by cattle, sheep and goats. They were required to give scores for each of the identified forage plants on a scale of 1 to 5 with a score of 1 being for the least preferred and 5 for the most preferred forage plants. The key forage species identified were ranked based on the total scores awarded by all the respondents. Forage value of the key forage plant species was calculated using the formula below (Ramshaw, 2017),

$$
\mathrm{F}=\sum(\mathrm{R}) / \mathrm{N}
$$

Where $\mathrm{F}$ is the importance rating based on forage plants preference by livestock as observed by herders

$\mathrm{R}$ is the total respondents' score for each species

$\mathrm{N}$ is the total number of respondents

Herbaceous forage production in each sub-plot $(1 \mathrm{~m} \times 5$ $\mathrm{m}$ ) was determined by clipping at $1 \mathrm{~cm}$ above the ground towards the end of long rainy season (June), and at the middle of the dry season (January), as they were assumed to have completed their physiological and phenological processes (growth) by this time. The freshly harvested herbage was oven-dried at $80{ }^{\circ} \mathrm{C}$ for 48 hours to obtain dry weight. The herbaceous forage dry matter per the $1 \mathrm{x}$ $5 \mathrm{~m}^{2}$ sub-plot was then converted to grams of dry matter per square metre.

Soil samples for testing bulk density were collected during wet and dry seasons to assess seasonal dynamics in soil bulk density and soil moisture content. Soil textural analysis was done using sieve method (Hinga et al., 1980). Sieves of different mesh sizes were used and soil samples were passed through each sieve. Sieve with 0.002 to 0.02 $\mathrm{mm}$ mesh size retained clay particles; the sieve with 0.02 to $0.2 \mathrm{~mm}$ retained silt particles, while the sieve with 0.2 to $2 \mathrm{~mm}$ retained sand particles. Quantities (by weight) of each textural type were determined and their proportion (percent) calculated. The soil textural classes were determined using the textural triangle and this guided determination of each study site's soil textural class.

Soil bulk density was analyzed using the auger-hole (gravimetric) method (Landon, 1991). The fresh weight of each sample was obtained using soil auger and weighed. The sample was oven-dried at $105{ }^{\circ} \mathrm{C}$ for 24 hours to obtain the dry weight. This dry weight of soil sample was divided by volume from the hole left by soil auger where the sample was obtained, to get the bulk density.

Soil Bulk density $=\underline{\text { Dry weight of soil }}$

Volume of hole

Soil moisture was obtained by getting the difference between the fresh and dry weight of the soil samples and expressing this as percentage of fresh weight.

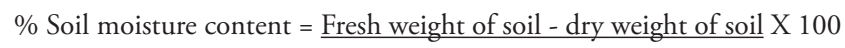
Fresh weight of soil

\section{Data Analysis}

The data collected was analyzed qualitatively and quantitatively using PAST and STATA statistical programs. Descriptive (tabulation) and inferential statistics were used. The inferential statistics used include regression, correlation, and t-test. Forage biomass production for the two rangelands expressed in dry matter weight per unit area was tabulated for January 2014 and January 2016. This was tabulated against soil bulk density and soil moisture content. Regression analysis was then done to establish the strength of influence of soil bulk density and soil moisture content on herbaceous forage biomass production.

\section{RESULTS}

\section{Key herbaceous forage species identified in Kivaa and Ntugi rangelands}

A number of herbaceous species considered as providing valuable forage were identified by the various respondents interviewed who included local livestock herders (agropastoralists), livestock production and extension officers, and local elders who are considered knowledgeable about multipurpose trees and shrubs. These forage species were scored based on their perceived forage value, and the total scores were used to rank them as earlier explained. These scores were used to calculate the actual forage value of 
each species. It was observed that forage value of a species changed with seasons with June representing (end of) wet season, while January represents (middle of) dry season. In Kivaa, herbaceous plants having the highest forage value during the dry season were Digitaria abyssinica (A. Rich.) Stapf, Chloris roxburghiana Schult., Dicanthium annulatum (Forssk.) Stapf), Cenchrus ciliaris L., and Digitaria milanjianus (Rendle) Stapf. During the wet season, the plants with the highest forage value in Kivaa, were Eleusine indica (L.) Gaertn, Themeda triandra Forssk.), Dicanthium annulatum and Digitaria abyssinica. In Ntugi, herbaceous plant species with the highest forage value during the dry season, were Cenchrus ciliaris, Digitaria abyssinica, Chloris roxburghiana and Rhynchelytrum repens (Willd.) C.E. Hubb. During the wet season, Cyperus rotundus L., Sonchus oleracea L. and Commelina benghalensis Linn. showed the highest forage value (Table 1).

\section{Soil textural type and its influence on moisture retention and productivity of herbaceous forage plants}

Analysis of soil types based on soil texture revealed that the percentage of clay in soils in Kivaa (mean 12.00) was significantly lower than the percentage of clay in soils in Ntugi (mean 18.60) $(t=3.30, P=0.004)$. Thus, soils in Ntugi were more clayey while the percentage of silt in soils in Kivaa (mean 18.80) was higher than the percentage of silt in soils from Ntugi (mean 12.40), $\mathrm{t}=4.68, \mathrm{P}=$ 0.0001 ) making Kivaa soils siltier. The percentage of sand in the soils from the two watersheds was not significantly different though the soils in Kivaa were sandier than those of Ntugi. From the results obtained, soils in Ntugi ranged from clay loam to sandy clay while those from Kivaa ranged from silty loam to sandy loam. Thus, soils in Ntugi seemed to have higher water retention capacity owing to their clayey nature as compared to the sandier soils in Kivaa (Table 2).

Differences in soil textural properties (soil types) also translated to differences in soil bulk density, which also influences soil moisture retention capacity. Sections of Kivaa and Ntugi watersheds dominated by clayey and loamy soils produced more forage herbage, compared to sites where sandy soils dominated. This can be attributed to the clayey and loamy soils' higher water retention capacities which ensured that plants growing where these soils dominated continued having moisture availability long after cessation of seasonal rainfall.

\section{Effect of soil moisture on herbaceous forage biomass production}

It was observed that there was higher percent moisture content in soils in Ntugi compared to soils in Kivaa (Table 3). Statistical analysis of soil moisture content in the two watersheds using unpaired t-test revealed that percent soil moisture content was significantly higher in Ntugi than in Kivaa at $(\mathrm{t}=7.71, \mathrm{p} \leq 0.05)$. This can be attributed to the fact that Ntugi rangelands received higher rainfall and coupled with clayey soils then there was more moisture available for herbaceous forage plants. Consequently, during wet seasons herbaceous forage species produced more herbage compared to dry seasons. On herbaceous forage biomass production, it was observed that Ntugi produced higher biomass compared to Kivaa, though the mean herbaceous forage plants' biomass production was not significantly different in the two rangelands $(t=1.41$; $\mathrm{p} \geq 0.05$ ).

Soil moisture content in Kivaa in 2014 had significant influence on herbaceous forage biomass production $(\mathrm{R}=$ 0.968, $\mathrm{p} \leq 0.05)$. Similarly, soil moisture content in Ntugi had significant positive influence in herbaceous forage biomass production $(\mathrm{R}=0.962, \mathrm{p} \leq 0.05)$. On the contrary, soil moisture content in Kivaa rangelands in 2016 had less significant influence on herbaceous forage species biomass production $(\mathrm{R}=0.0309, \mathrm{p} \geq 0.05)$. However, in Ntugi, in 2016, soil moisture exerted significant influence on herbaceous forage species biomass production $(\mathrm{R}=0.427$, $\mathrm{p} \leq 0.05)$. These results imply that soils having higher moisture content produced higher herbaceous forage biomass as was the case with soils from Ntugi.

\section{Influence Soil bulk density on herbaceous forage biomass production}

There was some relationship between soil bulk density and herbaceous forage species biomass production (Table 4). Statistical analysis of the two rangelands' soil bulk densities revealed that soils in Ntugi had higher soil bulk density than soils in Kivaa, though this difference was not significant at $\mathrm{p} \leq 0.05 \mathrm{p} \leq 0.05(\mathrm{t}=1.51, \mathrm{p}=0.15)$. Mean herbaceous forage biomass production was higher in Ntugi than in Kivaa. However, this difference was not significant $(\mathrm{t}=1.410, \mathrm{p}=0.179)$. Statistical analysis revealed that soil bulk density positively and significantly influenced forage species biomass production in Ntugi in $2014(\mathrm{R}=0.513$, $\mathrm{P}=0.019)$ and in $2016(\mathrm{R}=0.632, \mathrm{p}=0.005)$. Thus, an increase in soil bulk density led to increased forage grass species biomass production and significant decrease in non-grass forage species biomass production $(R=-0.141$, $\mathrm{P}=0.023$ ). This could be attributed to the ability of grass to grow and absorb water in relatively compact soils and also due to relatively compact soils being able to store water for a longer time as compared to less compact soils. In Kivaa rangelands soil bulk density did not significantly influence forage biomass but it significantly influenced herbaceous ground cover in $2014(\mathrm{R}=0.484, \mathrm{p}=0.025)$. 
Table 1. Herbaceous forage species found in Kivaa and Ntugi and their forage values.

\begin{tabular}{|c|c|c|c|c|c|c|}
\hline \multicolumn{7}{|c|}{ Kivaa Rangelands - Key herbaceous forage species and their Forage values } \\
\hline \multirow[b]{2}{*}{ Forage plant species } & \multicolumn{3}{|c|}{ January 2013} & \multicolumn{3}{|c|}{ June 2014} \\
\hline & $\begin{array}{r}\text { Total } \\
\text { Score/100 }\end{array}$ & $\begin{array}{r}\text { Forage } \\
\text { value/5 }\end{array}$ & Rank & $\begin{array}{r}\text { Total } \\
\text { score/100 }\end{array}$ & $\begin{array}{r}\text { Forage } \\
\text { value/5 }\end{array}$ & Rank \\
\hline Cenchrus ciliaris & 81 & 4.05 & 4 & 75 & 3.75 & 7 \\
\hline Rhynchelytrum repens & 70 & 3.50 & 9 & 56 & 2.80 & 15 \\
\hline Themeda triandra & 72 & 3.60 & 7 & 90 & 4.50 & 2 \\
\hline Dichanthium annulatum & 82 & 4.10 & 3 & 90 & 4.50 & 2 \\
\hline Digitaria macroblephara & 73 & 3.65 & 6 & 66 & 3.30 & 9 \\
\hline Eragrostis superba & 70 & 3.50 & 9 & 80 & 4.00 & 5 \\
\hline Eleusine indica & 69 & 3.45 & 11 & 100 & 5.00 & 1 \\
\hline Sporobolus festivus & 69 & 3.45 & 11 & 50 & 2.50 & 16 \\
\hline Enteropogon macrostachyus & 72 & 3.60 & 7 & 60 & 3.00 & 10 \\
\hline Commelina benghalensis & 48 & 2.40 & 16 & 60 & 3.00 & 10 \\
\hline Digitaria abyssinica & 98 & 4.90 & 1 & 83 & 4.15 & 4 \\
\hline Cyperus rotundus & 65 & 3.25 & 13 & 77 & 3.85 & 7 \\
\hline Chloris roxburghiana & 97 & 4.85 & 2 & 60 & 3.00 & 10 \\
\hline Panicum coloratum & 58 & 2.90 & 14 & 60 & 3.00 & 10 \\
\hline Digitaria milanjianus & 80 & 4.00 & 5 & 60 & 3.00 & 10 \\
\hline Aristida keniensis & 58 & 2.90 & 14 & 80 & 4.00 & 5 \\
\hline \multicolumn{7}{|c|}{ Ntugi Rangelands - Key herbaceous forage species and their forage values } \\
\hline Rhynchely trumrepens & 51 & 2.55 & 5 & 53 & 2.65 & 5 \\
\hline Digitaria abyssinica & 57 & 2.85 & 2 & 55 & 2.75 & 4 \\
\hline Cyperus rotundus & 37 & 1.85 & 7 & 66 & 3.30 & 1 \\
\hline Cenchrus ciliaris & 58 & 2.90 & 1 & 50 & 2.50 & 6 \\
\hline Chloris roxburghiana & 54 & 2.70 & 3 & 50 & 2.50 & 6 \\
\hline Aristida keniensis & 32 & 1.60 & 8 & 40 & 2.00 & 10 \\
\hline Sonchus oleracea & 30 & 1.50 & 9 & 60 & 3.00 & 2 \\
\hline Sporobolus festivus & 53 & 2.65 & 4 & 50 & 2.50 & 6 \\
\hline Commelina banghalensis & 28 & 1.40 & 10 & 60 & 3.00 & 2 \\
\hline Setaria verticillata & 48 & 2.40 & 6 & 50 & 2.50 & 6 \\
\hline
\end{tabular}

Table 2. Soil textural classes and herbage production in Kivaa and Ntugi in 2014 and 2016.

\begin{tabular}{|l|l|l|l|l|l|l|}
\hline $\begin{array}{l}\text { Plot/ } \\
\text { Sample } \\
\text { No. }\end{array}$ & $\begin{array}{l}\text { Kivaa Soil } \\
\text { textural class } \\
2014\end{array}$ & $\begin{array}{l}\text { Forage herbage } \\
\text { yield }\left(\mathrm{gDMm}^{-2}\right) \\
\text { January 2014 }\end{array}$ & $\begin{array}{l}\text { Kivaa soil Textural } \\
\text { class 2016 }\end{array}$ & $\begin{array}{l}\text { Ntugi Soil Textural } \\
\text { class 2014 }\end{array}$ & $\begin{array}{l}\text { Forage herbage yield } \\
\left(\mathrm{gDMm}^{-2}\right) \\
\text { January 2014 }\end{array}$ & $\begin{array}{l}\text { Ntugi Soil } \\
\text { Textural class } \\
2016\end{array}$ \\
\hline 1. & Loamy sand & 77.30 & Sandy loam & Sandy Loam & 139.10 & Sandy loam \\
\hline 2. & Loamy sand & 62.72 & Sandy loam & Sandy Loam & 155.67 & Sandy loam \\
\hline 3. & Sandy loam & 56.94 & Sandy loam & Sandy Loam & 141.43 & Sandy loam \\
\hline 4 & Sandy loam & 68.75 & Sandy loam & Loam & 187.50 & Sandy clay \\
\hline 5. & Loamy sand & 53.45 & Sandy loam & Sandy Loam & 209.24 & Sandy clay \\
\hline 6. & Loamy sand & 43.50 & Sandy loam & Loamy Sand & 197.90 & Sandy clay \\
\hline 7. & Sandy loam & 64.76 & Sandy loam & Silt Loam & 193.74 & Sandy clay \\
\hline 8. & Sandy loam & 70.10 & Sandy loam & Silty Loam & 180.20 & Sandy clay \\
\hline 9. & Sandy loam & 86.90 & Sandy loam & Loamy Sand & 161.34 & Silty loam \\
\hline 10. & Sandy loam & 50.78 & Sandy loam & Silt Loam & 185.42 & Silty loam \\
\hline
\end{tabular}


Table 3. Mean percent soil moisture content and herbaceous forage biomass

\begin{tabular}{|c|c|c|c|c|c|c|c|c|}
\hline \multicolumn{5}{|c|}{ Kivaa Rangelands } & \multicolumn{4}{|c|}{ Ntugi Rangelands } \\
\hline Plot & $\begin{array}{l}\text { January } \\
2014 \\
\% \text { moisture }\end{array}$ & $\begin{array}{l}\text { January } \\
2014 \\
\text { Forage } \\
\text { gDMm }^{-2}\end{array}$ & $\begin{array}{l}\text { January } 2016 \\
\text { \% Moisture }\end{array}$ & $\begin{array}{l}\text { January } 2016 \\
\text { Forage gDMm² }\end{array}$ & $\begin{array}{l}\text { January } \\
2014 \\
\% \text { Moisture }\end{array}$ & $\begin{array}{l}\text { January2014 } \\
\text { Forage } \\
\text { gDMm }^{-2}\end{array}$ & $\begin{array}{l}\text { January } \\
2016 \\
\% \text { Moisture }\end{array}$ & $\begin{array}{l}\text { January } 2016 \\
\text { Forage } \\
\text { gDMm }^{-2}\end{array}$ \\
\hline 1 & 1.6 & 77.30 & 1.8 & 82.07 & 2.2 & 139.10 & 2.4 & 148.91 \\
\hline 2 & 1.2 & 62.72 & 1.0 & 92.79 & 3.2 & 155.67 & 3.0 & 125.80 \\
\hline 3 & 1.0 & 56.94 & 1.2 & 127.94 & 2.3 & 141.43 & 2.5 & 143.83 \\
\hline 4 & 1.3 & 68.75 & 1.5 & 124.80 & 4.0 & 187.50 & 4.2 & 198.38 \\
\hline 5 & 1.0 & 53.45 & 1.1 & 141.65 & 5.2 & 209.24 & 5.5 & 199.86 \\
\hline 6 & 0.8 & 43.50 & 0.7 & 134.83 & 4.5 & 197.90 & 4.8 & 198.72 \\
\hline 7 & 1.2 & 64.76 & 1.4 & 194.89 & 4.2 & 193.74 & 4.4 & 146.84 \\
\hline 8 & 1.3 & 70.10 & 1.1 & 183.96 & 3.8 & 180.20 & 4.0 & 216.98 \\
\hline 9 & 1.7 & 86.90 & 1.8 & 189.02 & 3.4 & 161.34 & 3.5 & 154.24 \\
\hline 10 & 1.0 & 50.78 & 0.8 & 221.29 & 3.9 & 185.42 & 4.0 & 213.39 \\
\hline
\end{tabular}

Table 4. Soil bulk density and herbaceous forage biomass for Kivaa and Ntugi Rangelands in 2014 and 2016

\begin{tabular}{|c|c|c|c|c|c|c|c|c|}
\hline \multirow[t]{2}{*}{ Plot } & \multicolumn{4}{|c|}{ Kivaa Rangelands } & \multicolumn{4}{|c|}{ Ntugi Rangelands } \\
\hline & $\begin{array}{l}\text { Soil bulk } \\
\text { density } \\
\text { January } \\
2014\end{array}$ & $\begin{array}{l}\text { Forage } \\
\text { herbage yield } \\
\left(\mathrm{gDMm}^{-2}\right) \\
\text { January } 2014\end{array}$ & $\begin{array}{l}\text { Soil bulk } \\
\text { density } \\
\text { January } 2016\end{array}$ & $\begin{array}{l}\text { Forage } \\
\text { herbage yield } \\
\left(\mathrm{gDMm}^{-2}\right) \\
\text { January } 2016\end{array}$ & $\begin{array}{l}\text { Soil bulk } \\
\text { density } \\
\text { January } \\
2014\end{array}$ & $\begin{array}{l}\text { Forage } \\
\text { herbage yield } \\
\left(\mathrm{gDMm}^{-2}\right) \\
\text { January } 2014\end{array}$ & $\begin{array}{l}\text { Soil bulk } \\
\text { density } \\
\text { January } 2016\end{array}$ & $\begin{array}{l}\text { Forage } \\
\text { herbage yield } \\
\left(\mathrm{gDMm}^{-2}\right) \\
\text { January } 2016\end{array}$ \\
\hline 1 & 1.72 & 77.30 & 1.44 & 82.07 & 2.59 & 139.10 & 2.37 & 148.91 \\
\hline 2 & 1.36 & 62.72 & 1.59 & 92.79 & 2.67 & 155.67 & 2.57 & 125.80 \\
\hline 3 & 1.62 & 56.94 & 1.54 & 127.94 & 2.56 & 141.43 & 2.37 & 143.83 \\
\hline 4 & 1.18 & 68.75 & 1.42 & 124.80 & 2.14 & 187.50 & 2.12 & 198.38 \\
\hline 5 & 1.39 & 53.45 & 1.34 & 141.65 & 1.93 & 209.24 & 2.09 & 199.86 \\
\hline 6 & 1.22 & 43.50 & 1.29 & 134.83 & 2.01 & 197.90 & 1.97 & 198.72 \\
\hline 7 & 1.31 & 64.76 & 1.25 & 194.89 & 2.08 & 193.74 & 2.17 & 146.84 \\
\hline 8 & 1.72 & 70.10 & 1.44 & 183.96 & 2.02 & 180.20 & 1.95 & 216.98 \\
\hline 9 & 1.66 & 86.90 & 1.59 & 189.02 & 1.79 & 161.34 & 1.95 & 154.24 \\
\hline 10 & 1.75 & 50.78 & 1.54 & 221.29 & 1.84 & 185.42 & 1.68 & 213.39 \\
\hline
\end{tabular}

\section{DISCUSSION}

Highly valuable herbaceous forage species included Digitaria abyssinica, Chloris roxburghiana, Dicanthium annulatum, Cenchrus ciliaris, Digitaria milanjianus, Eleusine indica, Themeda triandra, and Rhynchelytrum repens. Cyperus rotundus, Sonchus oleracea and Commelina benghalensis were more valuable as forage during the wet season but were not considered reliable due to their ephemeral nature as well as their low adaptability and resilience. On the contrary, grass forage species showed high adaptability and resilience even during the dry seasons. Their fibrous root system may have been responsible for the high adaptability and resilience.

A study by Mganga et al. (2013) found that native Kenyan rangeland forage such as C. ciliaris, Eragrostis superba Peyr. and Enteropogon macrostachyus (Hochst. Ex A. Rich.) were the most suitable for combating desertification and were also the most preferred among the local agro-pastoralists. The study (Mganga et al., 2013) revealed that, regarding grazing value, local agro-pastoralists preferred E. superba followed by Cenchrus ciliaris and E. macrostachyus in that order. These results showed that agro-pastoralists' preference for a particular grass species was motivated more by its grazing value than its usefulness in rehabilitation of degraded parts. The findings agree with those of this study which also found C. ciliaris to be a suitable and highly preferred forage species by agro-pastoralists in Eastern Kenya.

Opiyo et al. (2011) found that some grass species serve as important forage as well as good soil cover and can therefore be used for reseeding degraded grazing lands. These include C. ciliaris, Chloris gayana, E. macrostachyus, E. superba, Cynodon dactylon and Chloris roxburghiana. Opiyo et al. (2011) concluded that C. ciliaris, E. macrostachyus and E. superba may have developed mechanisms which enables them to adapt to relatively hostile conditions and degraded 
areas. Many of these grass species have multiple uses, such as forage, source of income, thatching material and for rehabilitation of degraded areas.

Textural properties of soils from Kivaa and Ntugi influenced soil moisture retention capacity. Soils in Ntugi, which were more clayey, had higher water retention capacity compared to the sandier soils of Kivaa rangelands. These soil textural differences were responsible for the differences in yields of herbaceous forage in the two rangelands, with Ntugi, which had clayey to loamy soils, producing more forage herbage compared to Kivaa rangelands, whose soils were largely sandy. Thus, clayey and loamy soils which have higher water retention capacities ensured that herbaceous plants continued growing due to adequate moisture long after seasonal rainfall had ended.

Ntugi rangelands produced higher herbaceous forage biomass compared to Kivaa which was attributed to the higher rainfall experienced there, and the clayey soils' ability to retain adequate moisture levels for continued growth of plants. These results imply that soils with higher moisture retention capacity produced higher herbaceous forage biomass, as was the case with soils from Ntugi. A previous study investigating the relationship between soil texture and moisture retention capacity found that sandy soils hold about $101.6 \mathrm{~mm}$ of available moisture within the depth of root penetration estimated at $1.22 \mathrm{~m}$. Loams, clay and clay loams store about 152.4, 203.2 and 177.8 $\mathrm{mm}$ of available water respectively, within the same depth $(1.22 \mathrm{~m})(\mathrm{GoA}, 2020)$. These findings concur with this research findings on influence of sandy and clayey soils on water retention and movement (percolation).

Soil bulk density in the two rangelands influenced herbaceous forage biomass production, though in Kivaa the influence was less significant as compared to Ntugi. This implies that soil bulk density had significant positive influence on (led to increase in) grass forage species biomass production in Ntugi. However, it was observed that higher soil bulk densities led to significant reduction in non-grass forage species biomass production. This could be attributed to the ability of grass species to grow and absorb moisture in relatively compact soils, as compared to non-grass herbaceous species, whose roots have reduced ability to penetrate through relatively compact soils. It was however found that moderately compact soils can store water for a longer period compared to less compact soils. In Kivaa rangelands soil bulk density did not significantly influence forage biomass but it significantly influenced herbaceous ground cover. The findings of this research also largely agree with those of research conducted by Arshad et al. (1996), who found that high soil bulk density was one problem that might cause poor plant functioning.
Some of the practices and causes of poor (high) soil bulk density include: continuous cultivation at the same depth, which promotes formation of hard pan; use of heavy equipment on wet soil which causes pulverization of the soil; lack of crop rotation which causes plant roots to overutilize nutrients at the same soil depth; burning or removing crop residues and overgrazing among others. Several measures or practices can be applied to address the problem of poor soil bulk density. For instance, tillage at the beginning of the growing season temporarily decreases bulk density and loosens compacted soil layers. However, if this tillage is followed by many animals or humans walking and trampling the cultivated field, then recompacting of soil may occur.

Grazing lands, which form large part of rangelands in arid and semi-arid areas are prone to soil compaction owing to overstocking. On such lands, poor soil bulk density can be addressed through application of grazing systems that minimize overstocking. Such grazing systems include rotational grazing systems such as paddocking, strip grazing and set stocking. These will give a previously utilized portion time to recover and this will allow soil to loosen. Other measures recommended to address or prevent occurrence of unfavorable soil bulk density include deep tillage, cover cropping and prescribed grazing, among others.

\section{CONCLUSION}

Herbaceous forage grass species namely; Digitaria abyssinica, Chloris roxburghiana, Dicanthium annulatum, Cenchrus ciliaris, Digitaria milanjianus, Eleusine indica, Themeda triandra, and Rhynchelytrum repens, Cyperus rotundus, and ephemerals such as Sonchus oleracea and Commelina benghalensis were observed to produce highly valuable forage. The ephemerals however could not be greatly relied upon since they disappeared during the dry periods only to resurface during wet seasons. They were therefore less resilient in the face of climatic adversity. Grass forage species showed high adaptability and resilience even during the dry seasons, perhaps due to their fibrous root system that may have enabled them to maximize on water absorption even during the lightest of showers.

Soil textural differences influence soil water retention capacity. Ntugi soils were more clayey and this was responsible for their higher water holding capacity compared to the Kivaa soils which were sandier thus having lower water retention capacity. Soil textural characteristics influence herbaceous forage plants biomass production. Clayey and loamy soils produced more herbage than sandy soils. These differences in herbaceous forage productivity can be largely attributed to the clayey 
and loamy soils' ability to retain more moisture compared to sandy soils. The higher water holding capacity in Ntugi soils as confirmed both experimentally and statistically made Ntugi rangelands to produce higher herbaceous forage biomass compared to Kivaa. From these results, it can be concluded that soil moisture content had significant influence on herbaceous forage biomass production.

Soil bulk density in the two rangelands influenced herbaceous forage biomass production, though in Ntugi the influence was stronger (more highly significant) compared to Kivaa. These results surprisingly indicate that moderate compaction (moderate soil bulk density) led to increased forage grass species biomass production while higher compaction (higher soil bulk density) led to significant reduction in non-grass herbaceous forage species biomass production. This can be attributed to low ability of non-grass forage species to penetrate and draw water from relatively compact soils. On the contrary, grass forage species were observed to have the ability to penetrate and absorb water from moderately compact soils. Moderately compact soils were observed to have the ability to store water for a longer period compared to less compact soils.

\section{ACKNOWLEDGEMENT}

I would like to appreciate the National Commission for Science, Technology and Innovation (NaCoSTI) for the research grant and also the Institute for Culture and Ecology for material support without which this research project would have been difficult to carry out.

\section{REFERENCES}

Arshad, M. A., Lowery B., \& Grossman B. (1996). Physical Tests for Monitoring Soil Quality. In: Doran J. W., Jones A. J., editors. Methods for assessing soil quality. Madison, WI. Pp.123-41.

Caplan, J. S., \& Yeakley, A. J. (2006). Rubus armeniacus (Himalayan blackberry) occurrence and growth in relation to soil and light conditions in western Oregon. Northwest. Science, 80, 9-17.

Carter, M. R. (1990). Relative measures of soil bulk density to characterize compaction in tillage studies on fine sandy loams. Cananadian Journal of Soil Science, 70, 425-433.

DeJong-Hughes, J. M., Swan, J. B., Moncrief, J. F., \& Voorhees, W. B. (2001). Soil compaction: Causes, effects, and control (revision). University of Minnesota Extension BU-3115-E.

Freysen, A. H., \&l Woldendorp, J. W. (1978). Structure and Functioning of Plant Populations. North-Holland Publishing Company, 1, 189.

Government of Alberta (2020). Soil moisture and temperature consideration. Factors that regulate plant growth. Retrieved from

https://www.alberta.ca/soil-moisture-andtemperature-consideration.aspx\#toc-0.2020.

Gikaba, J. M., Muthoni, K. S., \& Bebe, B. O. (2014). Influence of drought duration on livestock feeding practices by Maasai pastoralists in Kajiado County, Kenya. International Journal of Innovation and Applied Studies, 8 (1), 225-231.

Hinga, G., Muchena, F. N., \& Njihia, C. M. (1980). Physical and chemical methods of soil analysis. Ministry of Agriculture, National Agricultural Laboratories, Nairobi, Kenya.

Kranz, C. N., McLaughlin R. A., Johnson A., Miller G., \& Heitman J. L. (2020). The effects of compost incorporation on soil physical properties in urban soils. A concise review. Journal of Environmental Management, 261, 110209.

Landon, R. J. (1991). Booker Tropical Soil Manual: A Handbook for Soil Survey and Agricultural Land Evaluation in the Tropics and Sub-tropics. Booker Tate Ltd. Inc, New York.

MacOpiyo, L., Irungu, P., \& Elhadi, Y. M. (2013). Study of livestock, fodder, milk production and marketing in arid and semi-arid lands of Kenya-promotion and strengthening enterprises and market systems in droughtprone ASAL areas. Baseline report For Kajiado, West Pokot and Narok Counties, Kenya.

Maundu, P. M., Ngugi G. W., \& Kabuye G.H.S. (1999). Traditional Food Plants of Kenya. National Museums of Kenya, Nairobi, Kenya.

Mganga, K. N., Musimba K. R., Nyariki, D. M., \& Mwang'ombe, A. W. (2013).The choice of grass species to combat desertification in semi-arid Kenyan rangelands is greatly influenced by their forage value for livestock. Grass and Forage Science, 70 (1), 161-167

Opiyo, F. E. O., Mureithi, S.M., \& Ngugi, R. K. (2011). The influence of water availability on pastoralist's resource use in Kitui and Mwingi districts of Kenya. Journal of Human Ecology, 35(1), 43-52.

Ramshaw, A. (2017). The complete guide to acceptable survey response rates. Retrieved from https://www.genroe.com/ blog/acceptable-survey-response-rate-2/11504.

Regional Centre for Mapping of Resources for Development-RCMRD (2016). Climate Database. Retrieved from https://www.rcmrd.org/. 